\title{
SURTEK
}

1511 Washington Avenue - Golden, Colorado 80401 - [303] 278-0877 - FAX̆: [303] 278-2245
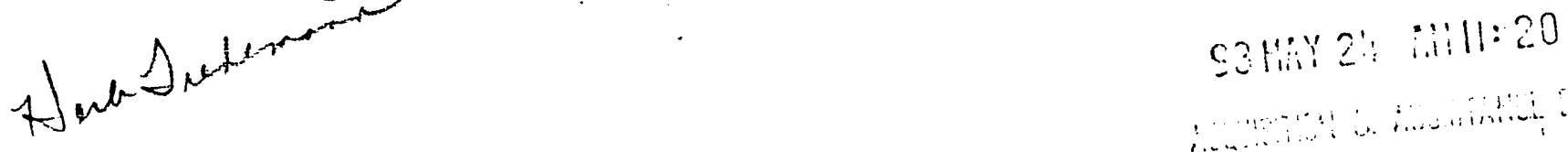

\author{
TECHNICAL PROGRESS REPORT \\ DOE Contract No DE-AC22-93BC14860 \\ Detailed Evaluation of the West Kiehl \\ Alkaline-Surfactant-Polymer Field Project \\ and It's Application to Mature Minnelusa Waterfloods
}

submitted by

Surtek, Inc.

Contract date: January 7, 1993

Anticipated Completion Date: September 30, 1994

Government Award for Fiscai Year October 1, 1992 to September 30, 1993: \$165,148

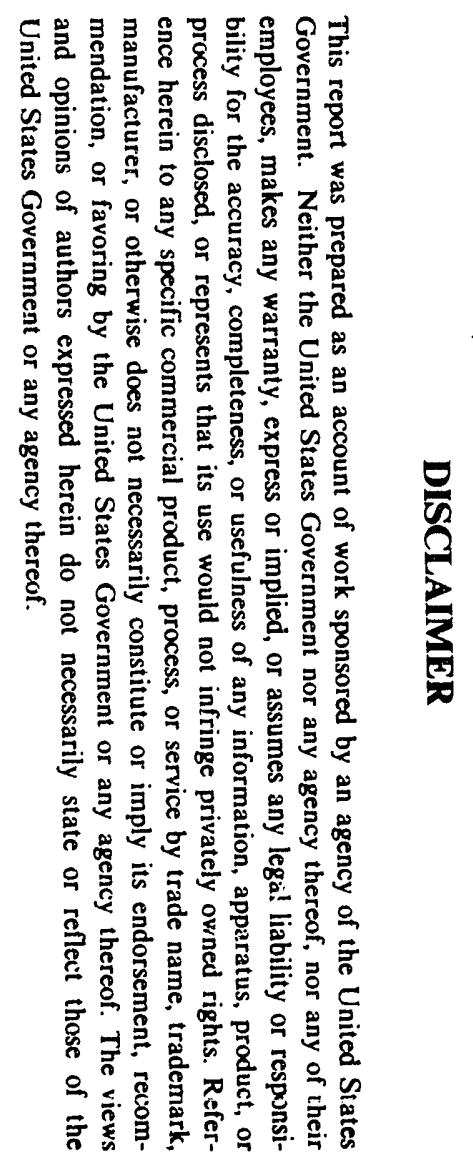

Principle Investigator: Malcolm J. Pitts

Surtek Program Manager: Harry Surkalo

Contract Specialist: William R. Mundorf

Contract Officer's Representative: Tom Reid -

RECEIVED

Report for the Period of January to March 1993

JUN 071993
OSTI

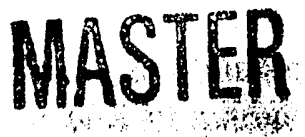

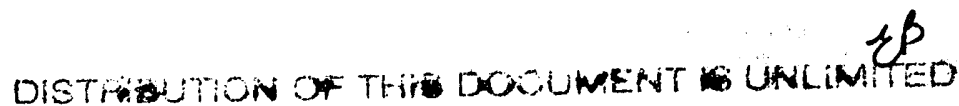




\section{Objectives of Study}

The objective of "Detailed Evaluation of the West Kiehl Alkaline-SurfactantPolymer Field Project and It's Application to Mature Minnelusa Waterfloods" is to 1) quantify the incremental oil produced from the West Kiehl alkaline-surfactantpolymer project by classical engineering and numerical simulation techniques, '2) to quantify the effect of chemical slug volume injection on incremental oil in the two swept areas of the field, 3) to determine the economic ramifications of the application of the alkaline-surfactant-polymer technology, 4) to forecast the results of injecting an alkaline-surfactant-polymer solution to mature waterfloods and polymer floods, and 5) to provide the basis for independent operators to book additional oil . reserves by using the alkaline-surfactant-polymer technology.

This report will document the initial geological and reservoir engineering data gathering. In addition, some of the initial laboratory results will be discussed. Some evaluation of the West Kiehl has been published. ${ }^{1,2}$

\section{Summary of Technical Progress}

Milestone 1 - Geological and Reservoir Engineering - A study area around the West Kiehl Field, located in Sections 25 and 36, Twp 53N, Rge 68W of Crook County, Wyoming, was selected to encompass sufficient productive Minnelusa oil fields to accomplish the objectives of the study. The area selected includes

Twp 51N - Rge 67W - Sections 4-9

Twp 51N - Rge 68W - Sections 1-12

Twp 51N - Rge 69W - Sections 1-3, 10-12

Twp 52N - Rge 67W - Sections 4-9, 16-21, 28-33

Twp 52N - Rge 68W - All Sections

Twp 52N - Rge 68W - Sections 1-3, 10-15, 22-27-34-36

Twp 53N - Rge 68W - All Sections

Twp 53N - Rge 69W - Sections 1-3, 10-15, 22-27, 34-36

Twp 54N - Rge 67W - Sections 4-9, 16-21, 28-33

Twp 54N - Rge 68W - All Sections

Twp 54N - Rge 69W - Sections-1-3, 10-15, 22-27, 34-36

Twp 55N - Rge 67W - Sections 28-33

Twp 55N - Rge 67.5W - Sections 25 \& 36

Twp 55N - Rge 68W - Sections 25-36

Twp 55N - Rge 69W - Sections 25-27, 34-36

This area includes over 1,500 Minnelusa penetrations and 62 separate Minnelusa oil producing reservoirs with cumulative production ranging from 3,200 to $9,481,300$ bcrrels. Table 1 list the Minnelusa fields being studied.

Logs and scout tickets were retrieved from the Denver Earth Resources Library on all of these wells. An east-to-west and north-to-south stratigraphic cross section grid of the Minnekahta and Minnelusa section was prepared on an approximate two-mile 
grid (10 east-to-west and 4 north-to-south). Utilizing the correlation grid, tops and porous intervals in the .Upper Minnelusa were determined for all of the wells within the study area. A data table was constructed listing a stratigraphic breakdown of the productive portion of the Minnelusa formation for all of the retrieved wells., This table includes the tops and bases of the sand units, their porous intervals, drill-stem tests and current oil production. The correlation and tabulation of this data is almost complete. The data table will be used to construct a series of geologic maps that will clearly define the geometry of the 62 producing Minnelusa reservoirs.

A series of geologic maps and cross sections were prepared for the West Kiehl Field. The cross sections were used to define three separate producing zones to be incorporated into the reservoir modeling. The structure and isopachus maps, constructed on a $1^{\prime \prime}=400^{\prime}$ scale, provide the basis for determining pore volumes for each of the zones. Porosity and water saturations from the logs were utilized to calculate hydrocarbon pore volumes. Analysis of the West Kiehl Field has resulted in the following:

\begin{tabular}{|c|c|c|c|}
\hline Well Number & Layer 1 & Layer 2 & Layer 3 \\
\hline & $\overline{\mathrm{H} \quad \mathrm{oH}}$ & $\overline{\mathrm{H}} \quad \mathrm{oH}$ & $\overline{\mathrm{H} \quad \mathrm{oH}}$ \\
\hline $25-10$ & 121.571 & 50.406 & 0.624 \\
\hline $25-15$ & 163.543 & $\begin{array}{ll}6 & 0.517\end{array}$ & 1.899 \\
\hline $31-36$ & 91.333 & 90.968 & 1.473 \\
\hline $42-36$ & 173.827 & 30.283 & $\begin{array}{ll}7 & 1.351\end{array}$ \\
\hline $32-36$ & 40.557 & 0 & 0 \\
\hline
\end{tabular}

A thorough search of available cores was conducted through the United States Geological Survey Core Repository in Denver and various industry sources. Since whole cores are preferable for laboratory analysis and general industry practice is to slab cores for analysis of sedimentary structure, the number of satisfactory cores available for the study is small. We were able to obtain three cores of productive Minnelusa reservoirs within the study area that we believe are representative of the West Kiehl reservoir and we are in the process of locating other whole cores.

As soon as the regional map suite is completed on a $1^{\prime \prime}=2000^{\prime}$ scale, ten or more fields will be selected for more detailed analysis as proposed in the "Statement of Work". Two will be selected from this list for reservoir simulation. On the basis of work completed to date at least five suitable Minnelusa reservoirs have been identified. They are: Cambridge, Kichl, Mellott Ranch, Prairie Creek South, and Semlek North

Milestone 2 - Laboratory and Numerical Simulation Study - The laboratory evaluations were initiated with collection of fluid and rock samples. Crude oil, injection water, and produced water were collected from the West Kiehl. Core 
samples were collected from two analogous oil reservoirs: Wolf Draw - Twp 52N Rge 68W - Section 18. and Guthery - Twp 51N - Rge 68W - Section 3.

Crude oil viscosity at $134^{\circ} \mathrm{F}$ was $16.9 \mathrm{cp}$ and the API gravity was degree. Produced water is currently contains none of the injected chemicals. The total dissolved solids is $8,100 \mathrm{mg} / \mathrm{l}$ and the hardness is $486 \mathrm{mg} / \mathrm{l}$ as $\mathrm{CaCO}_{3}$. Injection water is from the Fox Hills formation. The total dissolved solids is $838 \mathrm{mg} / \mathrm{l}$ and the hardness is $5 \mathrm{mg} / \mathrm{l}$ as $\mathrm{CaCO}_{3}$.

The interfacial tension at $134^{\circ} \mathrm{F}$ between West Kiehl crude oil and 0.8 wt\% $\mathrm{Na}_{2} \mathrm{CO}_{3}$ plus $0.1 \mathrm{wt} \%$ Petrostep. B-100 plus $1050 \mathrm{mg} / \mathrm{l}$ Pusher 700 is $0.017 \mathrm{mN} / \mathrm{m}$. Dilution with produced water decreased the interfacial tension. Dilution of the alkalinesurfactant-polymer solution with $20,40,60$, and $80 \%$ produced water increased the interfacial tension $2.7,3.9,13.8$, and 23.5 fold. These are consistent with previously published interfacial tension values. ${ }^{1}$ 


\section{References}

1. Clark, S.R., Pitts, M.J. and Smith, S.M.: "Design and Application of an Alkaline-Surfactant-Polymer Recovery System to the West Kiehl Field," SPE Advanced Technology Series, Vol 1, Number 1, April 1993, pages' .

2. Meyers, J.J., Pitts, M.J., and Wyatt, K.: "Alkaline-Surfactant-Polymer Flood of the West Kiehl, Minnelusa Unit,", SPE/DOE 24144. 


\begin{tabular}{|c|c|c|c|}
\hline \multicolumn{4}{|c|}{$\begin{array}{l}\text { MINNELUSA FIELD PRODUCTION - ASP STUDY } \\
\text { TWP } 51 \mathrm{~N} \text { to } 55 \mathrm{~N} \text { - RGE } 67 \mathrm{~W} \text { to } 69 \mathrm{~W}\end{array}$} \\
\hline \multirow[b]{2}{*}{ FIELD } & \multicolumn{3}{|c|}{ LOCATION } \\
\hline & SEC & TWP & RGE \\
\hline ALPHA & $1,2,11$ & $51 N$ & $69 W$ \\
\hline AMERICAN & 5,6 & $52 N$ & $68 W$ \\
\hline AMMO & 16,17 & $52 \mathrm{~N}$ & $68 W$ \\
\hline ASH & 27,28 & $52 \mathrm{~N}$ & $69 \mathrm{~W}$ \\
\hline BERGER HILL & 6 & $53 N$ & $69 W$ \\
\hline BRACKEN & 12,13 & $52 \mathrm{~N}$ & $69 W$ \\
\hline BRACKEN SOUTH & 13 & $52 N$ & $69 \mathrm{~W}$ \\
\hline BREAKS & 26 & $52 N$ & $69 \mathrm{~W}$ \\
\hline BREAKS SOUTH & 35 & $52 N$ & $69 W$ \\
\hline BRISLAWN & & $54 N$ & $68 W$ \\
\hline BROUSA DRAW & 8 & $53 N$ & $67 W$ \\
\hline CAMBRIDGE & 28 & $53 N$ & $68 W$ \\
\hline CARDINAL & 3 & $51 \mathrm{~N}$ & $69 W$ \\
\hline COUNTY LINE & 31 & $52 \mathrm{~N}$ & $68 W$ \\
\hline DEADMAN CREEK & 18,19 & $53 N$ & $67 \mathrm{~W}$ \\
\hline EDSEL & $25,26,35,36$ & $53 \mathrm{~N}$ & $68 W$ \\
\hline GUTHERY & 3 & $51 N$ & $68 W$ \\
\hline GUTHERY NORTH & 34,35 & $52 N$ & $68 W$ \\
\hline HEATH & $4,5,8,9$ & $53 N$ & $68 \mathrm{~W}$ \\
\hline HILDA & 36 & $52 N$ & $69 W$ \\
\hline HOOVER GULCH & 24 & $52 N$ & $69 W$ \\
\hline J B & 20 & $53 \mathrm{~N}$ & $68 W$ \\
\hline JEWEL & 7 & $53 N$ & $67 W$ \\
\hline KIEHL & 30,31 & $53 \mathrm{~N}$ & $67 \mathrm{~W}$ \\
\hline KIEHL WEST & 25,36 & $53 N$ & $68 W$ \\
\hline$L A D$ & $17-19$ & $54 N$ & $67 \mathrm{~W}$ \\
\hline LAD SE & -20 & $54 N$ & $67 \mathrm{~W}$ \\
\hline LILY & $27,34,35$ & $54 N$ & $68 W$ \\
\hline LITTLE MISSOURI & $5 ; 31,32$ & $54 \mathrm{~N}, 55 \mathrm{~N}$ & $67 W$ \\
\hline LITTLE MITCHELL CR & 11,14 & $52 N$ & $69 W$ \\
\hline LITTLE MO & 23,26 & $53 \mathrm{~N}$ & $68 W$ \\
\hline MD & $6 ; 1 ; 31,36$ & $52 \mathrm{~N}, 53 \mathrm{~N}$ & $68 W, 69 W$ \\
\hline M D NORTH & 25 & $53 N$ & $68 W$ \\
\hline MELLOTT RANCH & $2,10,11$ & $52 N$ & $68 W$ \\
\hline MISSOURI & 23 & $53 \mathrm{~N}$ & $68 \mathrm{~W}$ \\
\hline MOORCROFT & 31,32 & $52 N$ & $67 W$ \\
\hline MOORCROFT NORTH & 24 & $52 N$ & $68 W$ \\
\hline MOREL & 17 & $53 N$ & $68 \mathrm{~W}$ \\
\hline MULE HERDER & 32 & $53 N$ & $68 W$ \\
\hline OSHOTO & 21,22 & $53 N$ & $68 \mathrm{~W}$ \\
\hline OSHOTO NORTH & 22 & $53 N$ & $68 W$ \\
\hline
\end{tabular}


MINNELUSA FIELD PRODUCTION - ASP STUDY TWP $51 \mathrm{~N}$ to $55 \mathrm{~N}$ - RGE $67 \mathrm{~W}$ to $69 \mathrm{~W}$
$\mathrm{MNL}$ - list
$4 / 9 / 93$
62 FIELDS

\begin{tabular}{lrrr} 
& \multicolumn{3}{c}{ LOCATION } \\
FIELD & SEC & TWP & RGE \\
\hline OSHOTO SOUTH & 27 & $53 \mathrm{~N}$ & $68 \mathrm{~W}$ \\
OSHOTO SOUTH-C & 27 & $53 \mathrm{~N}$ & $68 \mathrm{~W}$ \\
PONDEROSA RIDGE & 21 & $53 \mathrm{~N}$ & $67 \mathrm{~W}$ \\
PRAIRIE CREEK & 6 & $53 \mathrm{~N}$ & $68 \mathrm{~W}$ \\
PRAIRIE CREEK SO & 16 & $53 \mathrm{~N}$ & $68 \mathrm{~W}$ \\
REYNOLDS RANCH & $6 ; 1$ & $52 \mathrm{~N}$ & $67 \mathrm{~W}, 68 \mathrm{~W}$ \\
RULE & 15 & $52 \mathrm{~N}$ & $69 \mathrm{~W}$ \\
SCRIBNER & 10 & $53 \mathrm{~N}$ & $69 \mathrm{~W}$ \\
SEMLEK & 27 & $52 \mathrm{~N}$ & $68 \mathrm{~W}$ \\
SEMLEK NORTH & 21 & $52 \mathrm{~N}$ & $68 \mathrm{~W}$ \\
SEMLEK NW & 21 & $52 \mathrm{~N}$ & $68 \mathrm{~W}$ \\
SEMLEK WEST & $28,29,33$ & $52 \mathrm{~N}$ & $68 \mathrm{~W}$ \\
SIDNER DRAW & 17 & $53 \mathrm{~N}$ & $67 \mathrm{~W}$ \\
SIMPSON NORTH & 10 & $51 \mathrm{~N}$ & $69 \mathrm{~W}$ \\
TERRACE & 11,12 & $51 \mathrm{~N}$ & $69 \mathrm{~W}$ \\
TERRY CRAW & & $54 \mathrm{~N}$ & $68 \mathrm{~W}$ \\
TEXAS TRAIL & 14,23 & $53 \mathrm{~N}$ & $68 \mathrm{~W}$ \\
TRAVA & 21 & $52 \mathrm{~N}$ & $67 \mathrm{~W}$ \\
WAGONSPOKE & $3 ; 34$ & $52 \mathrm{~N}, 53 \mathrm{~N}$ & $69 \mathrm{~W}$ \\
WILDFIRE & 21 & $53 \mathrm{~N}$ & $68 \mathrm{~W}$ \\
WOLF DRAW & 18 & $52 \mathrm{~N}$ & $68 \mathrm{~W}$
\end{tabular}



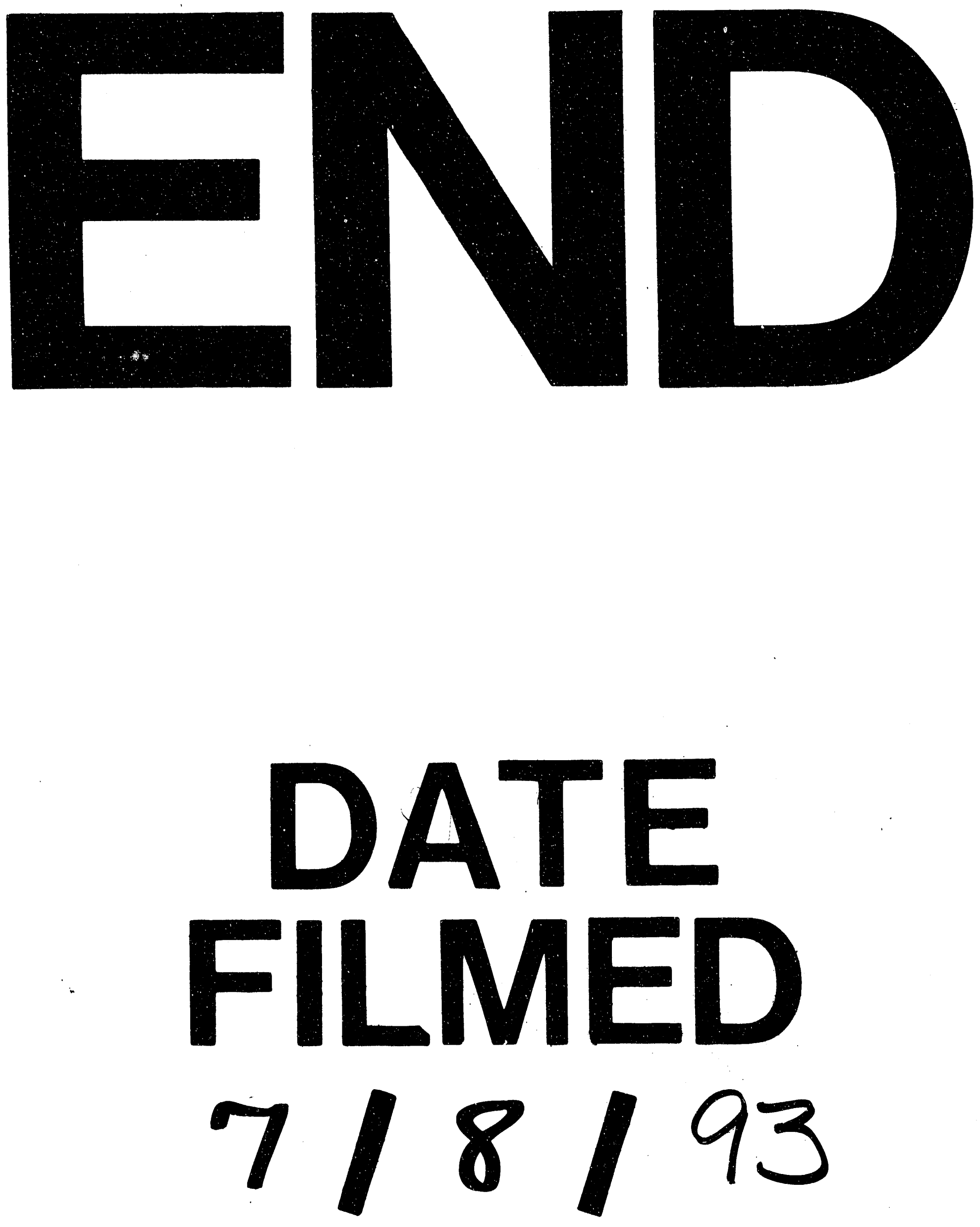

1 
